\title{
Conformational HIV-1 Envelope on particulate structures: a tool for chemokine coreceptor binding studies
}

\author{
Maria Tagliamonte', Maria Lina Tornesello', Franco M Buonaguro', Luigi Buonaguro ${ }^{1,2^{*}}$
}

\begin{abstract}
The human immunodeficiency virus type 1 (HIV-1) external envelope glycoprotein gp120 presents conserved binding sites for binding to the primary virus receptor CD4 as well as the major HIV chemokine coreceptors, CCR5 and CXCR4.

Concerted efforts are underway to understand the specific interactions between gp120 and coreceptors as well as their contribution to the subsequent membrane fusion process.

The present review summarizes the current knowledge on this biological aspect, which represents one of the key and essential points of the HIV-host cell interplay and HIV life cycle. The relevance of conformational HIV-1 Envelope proteins presented on Virus-like Particles for appropriate assessment of this molecular interaction, is also discussed.
\end{abstract}

\section{Introduction}

The molecular interaction between HIV-1 gp120, in its trimeric conformation, and the CD4 receptor on the host cell surface represents the first step of the HIV infection cycle. Upon this interaction, the co-receptorbinding site on the gp120 is exposed, enabling the binding to HIV chemokine coreceptors (mainly CCR5 or CXCR4) expressed on the surface of a subset of CD4+ lymphocytes. The binding to the coreceptors is followed by fusion of the viral and host cell membranes mediated by the HIV gp41 transmembrane glycoprotein [1-6].

Dissecting the structural changes which HIV external envelope glycoprotein gp120 molecule undergo upon molecular interactions with its cognate cellular receptor and coreceptors, provide essential information to the development of HIV-1-specific drugs, targeting the viral entry step [7-16], as well as of vaccines [17-20].

\section{Gp120 binding to chemokine coreceptors}

The HIV-1 Envelope is synthesized as the polyprotein precursor gp160, which undergoes oligomerization, disulfide bond formation and extensive glycosylation in the

\footnotetext{
* Correspondence: Ibuonaguro@tin.it

${ }^{1}$ Lab. of Molecular Biology and Viral Oncogenesis \& AIDS Reference Center,

Istituto Nazionale Tumori "Fond. G. Pascale", Naples, Italy

Full list of author information is available at the end of the article
}

endoplasmic reticulum [21]. The full post-translational processing and maturation lead to proteolytical cleavage of precursor gp160 into the surface gp120 and transmembrane gp41 subunits by furin-like endo-proteases in the Golgi network [22-24]. The two subunits will assemble into a trimer consisting of three gp120 molecules associated non-covalently with three gp41 subunits.

The molecular interaction of HIV gp120 with the CD4 receptor and, subsequently, with the CCR5 or CXCR4 coreceptor leads to the insertion of the hydrophobic gp41 N-terminal region (fusion peptide) into the host cell membrane. In particular, the gp41 ectodomain trimer acquires the six-helix bundle configuration which drives in close contact the viral and cell membranes, ultimately resulting in their fusion $[1,2,4,25,26]$. Therefore, the binding of HIV envelope to cellular coreceptors dramatically influence the strength of viral-cell interaction and promote the conformational changes in the gp41 required to overcome the energy barrier and induce pore formation and membrane fusion.

Within the CCR5 and CXCR4 amino acid residues interacting with the gp120, most of the cysteine residues are involved in disulfide bonds formation and play a key functional role. In particular, the $\mathrm{N}$-terminal and second extracellular domain (ECII) of both coreceptors seem to be critical for gp120-CD4 complex binding [27-35]. 
The role of coreceptors in the conformational changes of the HIV transmembrane gp41 to facilitate virus-cell membrane fusion has not yet been fully clarified, mainly due to the lack of the CCR5 and CXCR4 crystal structure and, therefore, their absence in high resolution $\mathrm{X}$-ray structures solved for CD4-bound gp120 [17]. The currently accepted theory proposes that, upon the coreceptor binding to the gp120-CD4 complex, the gp41 acquires the thermostable, six-helix bundle structure that brings the two membranes together and results in fusion pore formation [36,37].

The first step is the exposure of the hydrophobic fusion peptide at the $\mathrm{N}$ terminus of gp 41 which interacts with the target cell membrane, generating an intermediate, pre-hairpin state bridging the virus and cell membranes. The pre-hairpin then refolds into the stable, six-helix bundle core structure $[38,39]$, releasing sufficient energy to overcome the kinetic barrier $[40,41]$ and catalyzing the fusion of the two membranes [42]. Whether the fusion can occur with the free energy liberated during refolding of one or several trimers, is still debated [40,43] (Fig.1).
In the described stepwise process, the pre-hairpin state shows a relatively long half-life [44], representing a favorable target for inhibitory peptides $[45,46]$ as well as neutralizing antibodies specific for the gp41 HR1 and MPER regions [47-50].

Several data about the envelope/receptor interactions have been generated also for the simian counterpart of HIV (Simian Immunodeficiency Virus, SIV). Indeed, SIV $_{\text {mac }}$ is the natural etiological agent of the AIDS-like syndrome in Rhesus Macaques, which is the only available animal model for obtaining relevant information on AIDS pathogenesis [51-54] as well as for testing efficacy of antiviral therapeutics and vaccine candidates $[55,56]$.

Similarly to HIV-1, SIV infection starts with the highaffinity interaction of the gp120-gp41 envelope glycoprotein (Env) complex with CD4 on the target cell surface [57,58]. However, in contrast to HIV-1, different strains of SIV preferentially use CCR5 and not CXCR4 as coreceptor for entry [59-61], although they may show promiscuity in coreceptor usage, engaging alternative

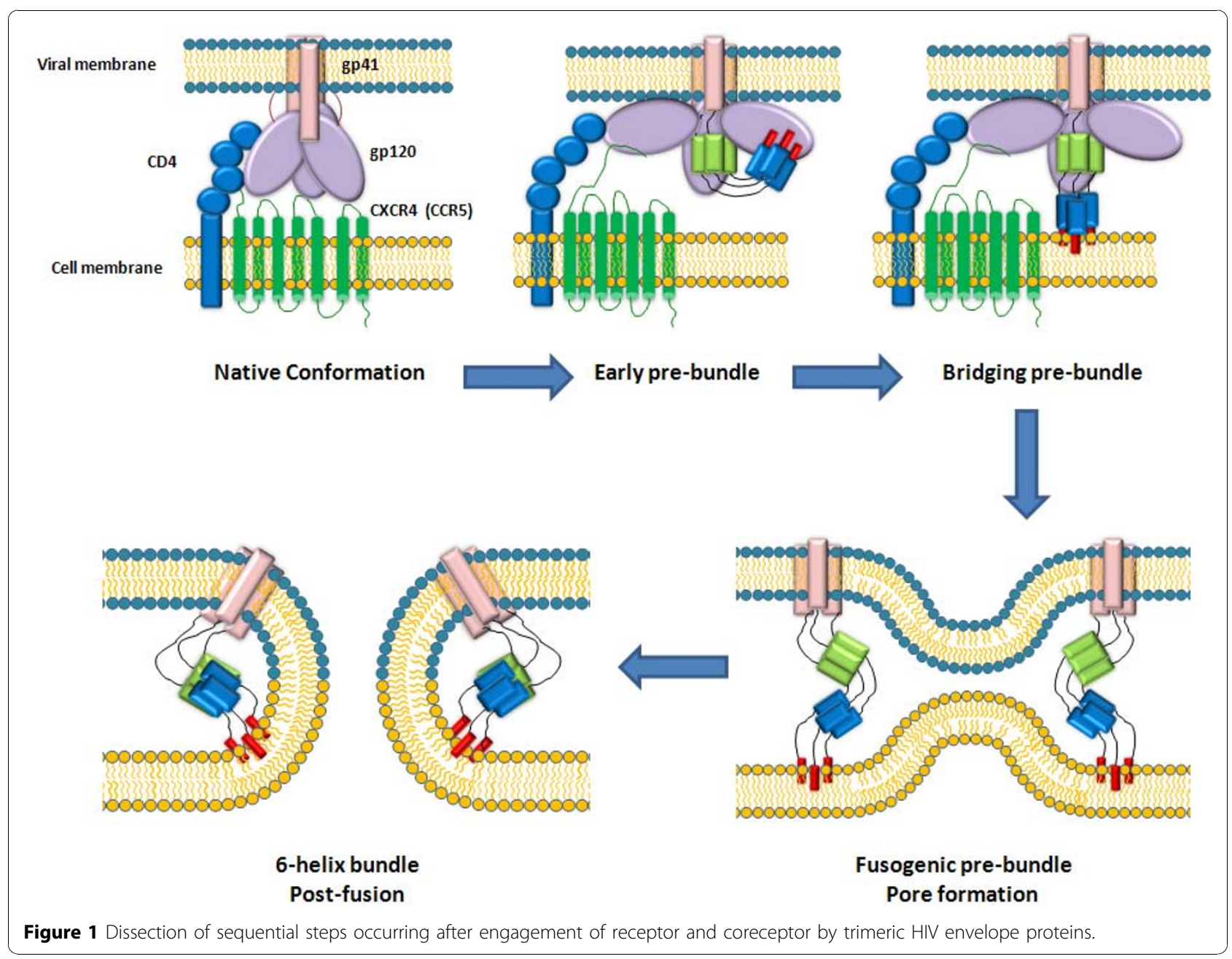


coreceptors GPR15 and CXCR6/STRL33 with high efficiency $[62,63]$.

Moreover, SIV strains have been shown to infect target cells via a CD4-independent pathway, directly interacting with CCR5 or CXCR4 coreceptor $[64,65]$. It has been proposed that Env protein of such strains contains multiple amino acid substitutions leading to the constitutive exposure of coreceptor binding site [66,67], similarly to what described for CD4-independent HIV-1 envelope proteins $[68,69]$. As consequence, CD4-independent viruses acquire a broader cell tropism, being able to infect also CD4 negative or low-expressing cells, such as macaque macrophages [70,71].

The molecular interaction of SIV envelope protein with the CD4 receptor and coreceptors leads to conformational changes in the gp41 ectodomain trimers and exposure of the fusion peptide which closely resemble what described for the HIV-1 counterpart [72,73].

\section{Role of coreceptors post-translational modifications in HIV-1-mediated cell fusion}

The effectiveness of CCR5 and CXCR4 as HIV coreceptors depends on the several possible conformations which may significantly influence their ability to support viral entry in different cells $[74,75]$.

Furthermore, post-translational modifications of HIV coreceptors and, in particular, of the extracellular domains (including the N-terminal, EC I - III) and intracellular loops, may modulate the receptor turnover as well as the binding efficacy to the HIV gp120. In general, extracellular domains may undergo N-linked or O-linked glycosylation and tyrosine sulfation, while modifications of intracellular loops include palmitoylation, phosphorylation, and ubiquitination [76-79].

CCR5. The CCR5 N-terminal is relevant for the role as HIV-1 coreceptor $[27,29,30]$ and contains several tyrosine residues which may be modified by sulfation, contributing to binding to natural ligands (MIP1- $\alpha$, MIP1- $\beta$ ) as well as HIV-1 gp120-CD4 complexes [80-82]. In particular, sulfation of Tyrosines at position 10 and 14 seems to be a requisite for the CCR5 binding efficacy [83,84]. Moreover, CCR5 is also modified by O-linked glycosylation, preferentially on Ser-6 $[85,86]$, although it does not seem to affect the role of CCR5 in the HIV entry [86].

As most chemokine receptors, the CCR5 carboxylterminus contains one or more cysteine residues compatible with receptor palmitoylation, typically located 12 to 25 amino acids away from the plasma membrane boundary [87]. Cysteine residues at amino acid positions 321,323 , and 324 undergo to palmitoylation, facilitating the CCR5 transport to the plasma membrane as well as ligand-stimulated endocytosis and affecting its ability to initiate intra-cellular signalling pathways [88-90].
However, the biological role of improved localization of CCR5 to lipid rafts for HIV entry into host cells is still disputed [88-92].

CXCR4. Similar to CCR5, also CXCR4 undergo posttranslational modifications contributing to its function. CXCR4 is sulfated at three tyrosine residues in the $\mathrm{N}$-terminus, with Tyr21 accounting for the majority of sulfate incorporation, although this modification doesn't appear to modulate the CXCR4 coreceptor function for HIV-1 [83].

In contrast to CCR5, the extracellular domain of CXCR4 is post-translationally modified by N-linked glycosylation in two potential sites, Asn11 and Asn176 [93,94], although only Asn11 appears to be glycosylated in mammalian cells [94]. Mutation of Asn11 does not impair the CXCR4-mediated HIV-1 infection [95,96]; however, a Asn11-to-Glu11 mutation leads to enhanced binding of both CXCR4-specific and dual-tropic (CCR5 and CXCR4) HIV-1 isolates [78,96].

\section{HIV-1 Envelope-coreceptor signaling}

The binding of the gp120-CD4 complex to chemokine coreceptors not only mediates HIV entry but also activates intracellular signaling cascades, mimicking chemokine signaling induced by binding to cognate receptors [97,98] (reviewed in [77,99,100].

However, in addition to signaling pathways mediating cell migration, transcriptional activation, cell growth and differentiation [101-106], binding of gp120-CD4 complex to CCR5 or CXCR4 coreceptor has also been shown to trigger the activation of proline-rich tyrosine kinase (Pyk2), phosphoinositide 3-kinases (PI3K) $[107,108]$ and CD4/CXCR4-dependent NFAT (nuclear factor of activated T cells) nuclear translocation [109]. Furthermore, gp120 was demonstrated to mediate chemotaxis, actin cytoskeleton rearrangement [108], and the activation of an actin depolymerization factor, cofilin, to increase the cortical actin dynamics in resting $\mathrm{CD} 4 \mathrm{~T}$ cells [110]. (For a more comprehensive description of gp120-triggered chemokines coreceptor signaling, refer to Cicala and Arthos in this same supplement).

\section{Stable trimeric forms of human immunodeficiency virus recombinant gp140}

As described above, the envelope proteins on the virus surface are assembled into trimers, consisting of three gp120 molecules associated non-covalently with three gp41 subunits, which interact sequentially with the CD4 receptor and the chemokine coreceptors, ultimately leading to viral and cell membrane fusion. In the last years, mainly aiming at inducing more potent and broader anti-HIV neutralizing antibodies, several groups have been developing soluble trimers of the gp120 gp41 Env ectodomain (i.e., lacking the transmembrane, 
cytoplasmic domains and named gp140) which are considered to preserve or mimic the structure of functional Env complexes [111-114]. Considering the close structural similarity of these molecules to native trimeric HIV Envelope proteins, this can represent a relevant tool also for receptor and chemokines coreceptor binding studies.

Mutations in the furin cleavage site at the gp120-gp41 junction inhibit the dissociation between the two envelope subunits [114-117], but cleavage-defective gp140 Env proteins seem to be antigenically different from fully processed Env [118-120]. In order to express processed and stable trimers of gp140, an intermolecular disulfide bond has been introduced between the gp120 and gp41 subunits to form a complex called "SOS" gp140 which, although still predominantly monomeric, strongly reacts with the broadly neutralizing b12mAb [118]. An isoleucine-to-proline substitution introduced at position 559 in the $\mathrm{N}$-terminal heptad region of gp41 has been shown to increase the stability of SOS gp140 (SOSIP gp140), leading to a fully cleaved and trimeric structure with optimal antigenic properties [121,122].

Moreover, cleavage-defective gp140 Env proteins have been further modified at the C-terminus to improve trimer formation and stabilization, fusing different heterologous trimerization motifs. In particular, a $32-$ amino-acid form of the GCN4 transcription factor $(\mathrm{GCN})$, a 27-amino-acid trimerization domain from the C-terminus of bacteriophage T4 fibritin (T4F), or a soluble trimerization domain of chicken cartilage matrix (CART) protein have been employed, showing enhanced binding to broadly neutralizing b12 and 2G12 mAbs $[115,116,123]$. More recently, the effectiveness of the catalytic chain of aspartate transcarbamoylase (ATCase) as trimerization domain for the HIV gp140 has been described [124,125].

\section{Exploiting the VLP model}

In addition to soluble forms, HIV gp140 trimeric complex can be presented on membrane structures including liposomes, inactivated viruses and virus-like particles (VLPs) or pseudovirions, to mimic as close as possible the native conformation [126-131].

In particular, Virus-like particles (VLPs) represent a complex structure based on viral capsid proteins which self-assemble into particulate structures closely resembling immature virus particles [132-135]. VLPs are replication as well as infection incompetent, lacking regulatory proteins as well as infectious genetic material, and can be considered nanoparticles and employed to deliver antigenic structures as well as DNA molecules to antigen presenting cells, for enhanced induction of immune responses against co-administered plasmid DNA-based immunogens [136-140].
VLPs have been produced from a broad spectrum of non-enveloped and enveloped viruses [140]. In particular, the particle structure of non-enveloped VLPs can be based on single or multiple capsid proteins without a surrounding cell membrane. Examples of such VLPs are those formed by the expression of the major capsid protein of papillomaviruses, parvoviruses and polyomaviruses [135,141-143] or by multiple interacting capsid proteins of Reoviridae family [144]. Alternative strategy for generating non-enveloped virus-like-particles (VLPs) is based on the assembly of the capsid protein derived from RNA bacteriophages [145-147].

Alternatively, enveloped VLPs are based on assembled capsid proteins surrounded by cell membrane and have been developed for enveloped viruses such as hepatitis B and $C$ virus (HBV \& $\mathrm{HCV}$ ), influenza $A$ and retroviruses, including HIV-1 [129,132,133,148-152].

The different forms of VLPs have distinct properties for displaying antigens, given that only enveloped VLPs may display full-length monomeric or multimeric conformational proteins on their surface through transmembrane domains [129-131,153]. Non-enveloped VLPs, on the contrary, may be employed to present mainly short peptides or protein sequences. This has been achieved either generating chimeric capsid proteins expressing foreign epitope in frame (eg. Gag:V3) [154-157], or chemically linking the foreign epitope to the assembled capsid protein [158], although HIV-1 Gag proteins fused to full-length HIV Reverse Transcriptase (RT) protein, without loosing the capability of assembling into VLPs, have been recently reported [159]. The conformational structure of full-length proteins possibly expressed on non-enveloped VLPs, however, remains to be proven.

As consequence, at present, only enveloped VLPs displaying full-length conformational proteins on their surface may be a suitable experimental model for studies on binding and interaction between HIV envelope and cellular receptor/coreceptors. They, indeed, represent the closest particle structure to native virus.

\section{Conformational HIV Envelopes presented on particulate structures}

Development of HIV-1 Pr55Gag-based VLPs expressing gp120/gp140 trimeric Envelope proteins is a goal pursued by several Groups, using different expression systems (mammalian vs baculovirus) as well as different trans-membrane domains. In particular, our group has previously developed Pr55gag-VLPs presenting a gp120 anchored through the trans-membrane (TM) portion of the Epstein-Barr virus (EBV) gp220/350, showing the formation of oligomeric structures [129] and inducing Env-specific humoral and cellular immune response [160-162]. Additional strategies have been more recently 
described to express trimeric forms of HIV-1 gp140 molecules on the surface of Pr55gag-VLPs [130,131]. Comparative studies showed that specific transmembrane domains induced optimal incorporation of gp140 Env trimers onto VLP surface, retaining conserved epitopes and undergoing conformational changes upon CD4 binding [131] (Buonaguro et al., submitted).

Considering the biological and structural properties of HIV gp140 trimers presented on the VLP surface, they can be even more strategic for binding studies, providing an invaluable tool for evaluating and dissecting the whole virus-host cell interaction leading to and ending with membrane fusion [163,164] (Fig. 2).

\section{Conclusions}

The interaction between HIV particles and target host cells is a defined temporally sequential stepwise process, characterized by the binding of surface gp120 Envelope protein to $\mathrm{CD} 4$ receptor and subsequent binding of the gp120-CD4 complex to chemokines coreceptors. This will ultimately lead to membrane fusion and host cell infection.

Studies aimed at dissecting the sequential steps of this process have been and will be instrumental not only to fully understand the strategies adopted by HIV to hijack host cells for its own replication but also to develop HIV-1-specific drugs and vaccines.

The development of novel and improved molecular tools, mimicking as close as possible native Envelope trimeric structures expressed on non-infectious particulate structures (i.e. VLPs), will expand the armamentarium for HIV-host cell interaction studies. This will help in shedding further light on such a key moment of the HIV infection as well as pathogenesis.

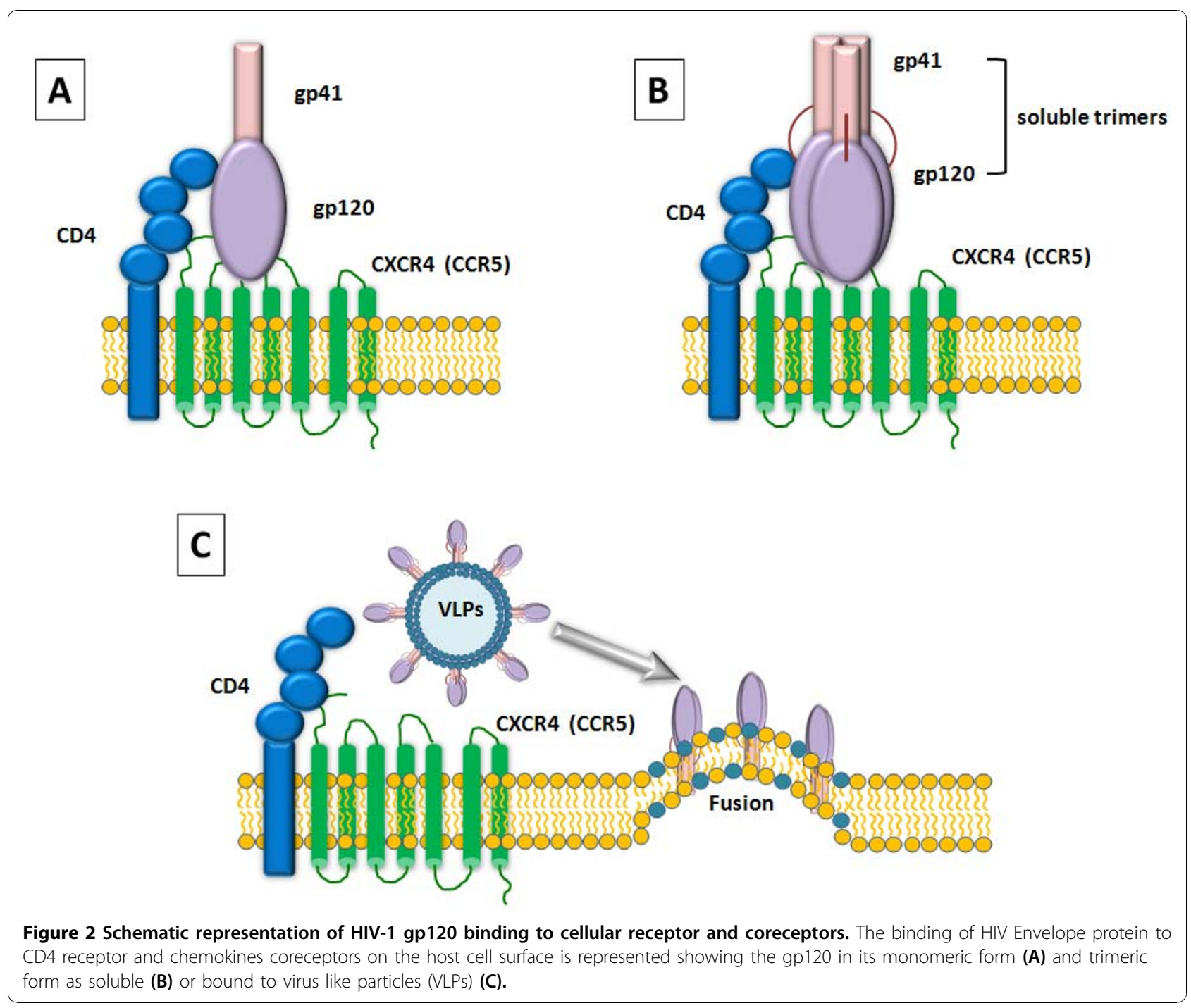




\section{Acknowledgements}

The study was supported by the European Community's Seventh Framework Programme NGIN (FP7/2007-2013) under grant agreement n 201433. MT was supported by the EU NGIN project.

This article has been published as part of Journal of Translational Medicine Volume 9 Supplement 1, 2011: Differential use of CCR5 vs. CSCR4 by HIV-1. Pathogenic, Translational and Clinical Open Questions. The full contents of the supplement are available online at http://www.translational-medicine. com/supplements/9/S1.

\section{Author details}

'Lab. of Molecular Biology and Viral Oncogenesis \& AIDS Reference Center, Istituto Nazionale Tumori "Fond. G. Pascale", Naples, Italy. ${ }^{2}$ Institute of Human Virology, University of Maryland School of Medicine, Baltimore, MD, USA.

\section{Competing interests}

The authors declare no competing financial or other interests.

Published: 27 January 2011

\section{References}

1. Doms RW, Moore JP: HIV-1 membrane fusion: targets of opportunity. J Cell Biol 2000, 151:F9-14.

2. Jones PL, Korte T, Blumenthal R: Conformational changes in cell surface HIV-1 envelope glycoproteins are triggered by cooperation between cell surface CD4 and co-receptors. J Biol Chem 1998, 273:404-409.

3. Sattentau QJ, Moore JP: Conformational changes induced in the human immunodeficiency virus envelope glycoprotein by soluble CD4 binding. J Exp Med 1991, 174:407-415.

4. Sullivan N, Sun Y, Sattentau Q, Thali M, Wu D, Denisova G, Gershoni J, Robinson J, Moore J, Sodroski J: CD4-Induced conformational changes in the human immunodeficiency virus type $1 \mathrm{gp} 120$ glycoprotein: consequences for virus entry and neutralization. J Virol 1998, 72:4694-4703.

5. Zhang W, Canziani G, Plugariu C, Wyatt R, Sodroski J, Sweet R, Kwong P, Hendrickson W, Chaiken I: Conformational changes of gp120 in epitopes near the CCR5 binding site are induced by CD4 and a CD4 miniprotein mimetic. Biochemistry 1999, 38:9405-9416.

6. Wyatt R, Sodroski J: The HIV-1 envelope glycoproteins: fusogens, antigens, and immunogens. Science 1998, 280:1884-1888.

7. Jacobson JM, Saag MS, Thompson MA, Fischl MA, Liporace R, Reichman RC, Redfield RR, Fichtenbaum CJ, Zingman BS, Patel MC, Murga JD, Pemrick SM, D'Ambrosio P, Michael M, Kroger H, Ly H, Rotshteyn Y, Buice R, Morris SA, Stavola JJ, Maddon PJ, Kremer AB, Olson WC: Antiviral activity of singledose PRO 140, a CCR5 monoclonal antibody, in HIV-infected adults. $J$ Infect Dis 2008, 198:345-1352.

8. Pett SL, McCarthy MC, Cooper DA, MacRae K, Tendolkar A, Norris R, Strizki JM, Williams KM, Emery S: A phase I study to explore the activity and safety of $\mathrm{SCH} 532706$, a small molecule chemokine receptor-5 antagonist in HIV type-1-infected patients. Antivir Ther 2009, 14:111-115.

9. Lalezari J, Yadavalli GK, Para M, Richmond G, Dejesus E, Brown SJ, Cai W, Chen C, Zhong J, Novello LA, Lederman MM, Subramanian GM: Safety, pharmacokinetics, and antiviral activity of HGS004, a novel fully human IgG4 monoclonal antibody against CCR5, in HIV-1-infected patients. J Infect Dis 2008, 197:721-727.

10. Dorr P, Westby M, Dobbs S, Griffin P, Irvine B, Macartney M, Mori J, Rickett G, Smith-Burchnell C, Napier C, Webster R, Armour D, Price D, Stammen B, Wood A, Perros M: Maraviroc (UK-427,857), a potent, orally bioavailable, and selective small-molecule inhibitor of chemokine receptor CCR5 with broad-spectrum anti-human immunodeficiency virus type 1 activity. Antimicrob Agents Chemother 2005, 49:4721-4732.

11. Wood A, Armour D: The discovery of the CCR5 receptor antagonist, UK427,857, a new agent for the treatment of HIV infection and AIDS. Prog Med Chem 2005, 43:239-271.

12. Hendrix CW, Collier AC, Lederman MM, Schols D, Pollard RB, Brown S, Jackson JB, Coombs RW, Glesby MJ, Flexner CW, Bridger GJ, Badel K, MacFarland RT, Henson GW, Calandra G: Safety, pharmacokinetics, and antiviral activity of AMD3100, a selective CXCR4 receptor inhibitor, in HIV-1 infection. J Acquir Immune Defic Syndr 2004, 37:1253-1262.

13. Stone ND, Dunaway SB, Flexner C, Tierney C, Calandra GB, Becker S, Cao YJ, Wiggins IP, Conley J, MacFarland RT, Park JG, Lalama C, Snyder S,
Kallungal B, Klingman KL, Hendrix CW: Multiple-dose escalation study of the safety, pharmacokinetics, and biologic activity of oral AMD070, a selective CXCR4 receptor inhibitor, in human subjects. Antimicrob Agents Chemother 2007, 51:2351-2358.

14. Princen $\mathrm{K}$, Hatse S, Vermeire K, Aquaro S, De CE, Gerlach LO, Rosenkilde M, Schwartz TW, Skerlj R, Bridger G, Schols D: Inhibition of human immunodeficiency virus replication by a dual CCR5/CXCR4 antagonist. J Virol 2004, 78:12996-13006.

15. Tagat JR, McCombie SW, Nazareno D, Labroli MA, Xiao Y, Steensma RW, Strizki JM, Baroudy BM, Cox K, Lachowicz J, Varty G, Watkins R: Piperazinebased CCR5 antagonists as HIV-1 inhibitors. IV. Discovery of 1-[(4,6dimethyl-5-pyrimidinyl)carbonyl]- 4-[4-[2-methoxy-1(R)-4-(trifluoromethyl) phenyl]ethyl-3(S)-methyl-1-piperaz inyl]- 4-methylpiperidine (Sch$417690 /$ Sch-D), a potent, highly selective, and orally bioavailable CCR5 antagonist. J Med Chem 2004, 47:2405-2408.

16. Baba M, Takashima K, Miyake H, Kanzaki N, Teshima K, Wang X, Shiraishi M, lizawa Y: TAK-652 inhibits CCR5-mediated human immunodeficiency virus type 1 infection in vitro and has favorable pharmacokinetics in humans. Antimicrob Agents Chemother 2005, 49:4584-4591.

17. Kwong PD, Wyatt R, Robinson J, Sweet RW, Sodroski J, Hendrickson WA: Structure of an HIV gp120 envelope glycoprotein in complex with the CD4 receptor and a neutralizing human antibody. Nature 1998, 393:648-659.

18. Dey B, Svehla K, Xu L, Wycuff D, Zhou T, Voss G, Phogat A, Chakrabarti BK, Li Y, Shaw G, Kwong PD, Nabel GJ, Mascola JR, Wyatt RT: Structure-based stabilization of HIV-1 gp120 enhances humoral immune responses to the induced co-receptor binding site. PLOS Pathog 2009, 5:e1000445.

19. Dormitzer PR, Ulmer JB, Rappuoli R: Structure-based antigen design: a strategy for next generation vaccines. Trends Biotechnol 2008, 26:659-667.

20. Zhou T, Georgiev I, Wu X, Yang ZY, Dai K, Finzi A, Do KY, Scheid J, Shi W, Xu L, Yang Y, Zhu J, Nussenzweig MC, Sodroski J, Shapiro L, Nabel GJ, Mascola JR, Kwong PD: Structural Basis for Broad and Potent Neutralization of HIV-1 by Antibody VRC01. Science 2010.

21. Earl PL, Moss B, Doms RW: Folding, interaction with GRP78-BiP, assembly, and transport of the human immunodeficiency virus type 1 envelope protein. J Virol 1991, 65:2047-2055.

22. Freed EO, Myers DJ, Risser R: Mutational analysis of the cleavage sequence of the human immunodeficiency virus type 1 envelope glycoprotein precursor gp160. J Virol 1989, 63:4670-4675.

23. McCune JM, Rabin LB, Feinberg MB, Lieberman M, Kosek JC, Reyes GR, Weissman IL: Endoproteolytic cleavage of gp160 is required for the activation of human immunodeficiency virus. Cell 1988, 53:55-67.

24. Hallenberger S, Bosch V, Angliker H, Shaw E, Klenk HD, Garten W: Inhibition of furin-mediated cleavage activation of HIV-1 glycoprotein gp160. Nature 1992, 360:358-361.

25. Melikyan GB, Markosyan RM, Hemmati $H$, Delmedico MK, Lambert DM, Cohen FS: Evidence that the transition of HIV-1 gp41 into a six-helix bundle, not the bundle configuration, induces membrane fusion. J Cell Biol 2000, 151:413-423.

26. Moore JP, Doms RW: The entry of entry inhibitors: a fusion of science and medicine. Proc Natl Acad Sci U S A 2003, 100:10598-10602.

27. Chabot DJ, Broder CC: Substitutions in a homologous region of extracellular loop 2 of CXCR4 and CCR5 alter coreceptor activities for HIV-1 membrane fusion and virus entry. J Biol Chem 2000, 275:23774-23782.

28. Alkhatib G, Locati M, Kennedy PE, Murphy PM, Berger EA: HIV-1 coreceptor activity of CCR5 and its inhibition by chemokines: independence from $\mathrm{G}$ protein signaling and importance of coreceptor downmodulation. Virology 1997, 234:340-348.

29. Doranz BJ, Lu ZH, Rucker J, Zhang TY, Sharron M, Cen YH, Wang ZX Guo HH, Du JG, Accavitti MA, Doms RW, Peiper SC: Two distinct CCR5 domains can mediate coreceptor usage by human immunodeficiency virus type 1. J Virol 1997, 71:6305-6314.

30. Dragic T, Trkola A, Lin SW, Nagashima KA, Kajumo F, Zhao L, Olson WC Wu L, Mackay CR, Allaway GP, Sakmar TP, Moore JP, Maddon PJ: Aminoterminal substitutions in the CCR5 coreceptor impair gp120 binding and human immunodeficiency virus type 1 entry. J Virol 1998, 72:279-285.

31. Kuhmann SE, Platt EJ, Kozak SL, Kabat D: Cooperation of multiple CCR5 coreceptors is required for infections by human immunodeficiency virus type 1. J Virol 2000, 74:7005-7015. 
32. Chabot DJ, Zhang PF, Quinnan GV, Broder CC: Mutagenesis of CXCR4 identifies important domains for human immunodeficiency virus type 1 X4 isolate envelope-mediated membrane fusion and virus entry and reveals cryptic coreceptor activity for R5 isolates. J Virol 1999, 73:6598-6609.

33. Brelot A, Heveker N, Adema K, Hosie MJ, Willett B, Alizon M: Effect of mutations in the second extracellular loop of CXCR4 on its utilization by human and feline immunodeficiency viruses. J Virol 1999, 73:2576-2586.

34. Kajumo F, Thompson DA, Guo Y, Dragic T: Entry of R5X4 and X4 human immunodeficiency virus type 1 strains is mediated by negatively charged and tyrosine residues in the amino-terminal domain and the second extracellular loop of CXCR4. Virology 2000, 271:240-247.

35. Zhou N, Luo Z, Luo J, Liu D, Hall JW, Pomerantz RJ, Huang Z: Structural and functional characterization of human CXCR4 as a chemokine receptor and HIV-1 co-receptor by mutagenesis and molecular modeling studies. J Biol Chem 2001, 276:42826-42833.

36. Golding H, Zaitseva M, de RE King LR, Manischewitz J, Sidorov I, Gorny MK, Zolla-Pazner S, Dimitrov DS, Weiss CD: Dissection of human immunodeficiency virus type 1 entry with neutralizing antibodies to gp41 fusion intermediates. J Virol 2002, 76:6780-6790.

37. Eckert DM, Kim PS: Mechanisms of viral membrane fusion and its inhibition. Annu Rev Biochem 2001, 70:77-810.

38. Chan DC, Fass D, Berger JM, Kim PS: Core structure of gp41 from the HIV envelope glycoprotein. Cell 1997, 89:263-273.

39. Weissenhorn W, Dessen A, Harrison SC, Skehel JJ, Wiley DC: Atomic structure of the ectodomain from HIV-1 gp41. Nature 1997, 387:426-430.

40. Harrison SC: Mechanism of membrane fusion by viral envelope proteins. Adv Virus Res 2005, 64:231-261.

41. Chernomordik LV, Kozlov MM: Protein-lipid interplay in fusion and fission of biological membranes. Annu Rev Biochem 2003, 72:175-207.

42. Melikyan GB, Markosyan RM, Hemmati H, Delmedico MK, Lambert DM, Cohen FS: Evidence that the transition of HIV-1 gp41 into a six-helix bundle, not the bundle configuration, induces membrane fusion. J Cell Biol 2000, 151:413-423.

43. Magnus C, Rusert P, Bonhoeffer S, Trkola A, Regoes RR: Estimating the stoichiometry of human immunodeficiency virus entry. J Virol 2009, 83:1523-1531.

44. Munoz-Barroso I, Durell S, Sakaguchi K, Appella E, Blumenthal R: Dilation of the human immunodeficiency virus-1 envelope glycoprotein fusion pore revealed by the inhibitory action of a synthetic peptide from gp41. J Cell Biol 1998, 140:315-323.

45. Wild CT, Shugars DC, Greenwell TK, McDanal CB, Matthews TJ: Peptides corresponding to a predictive alpha-helical domain of human immunodeficiency virus type $1 \mathrm{gp} 41$ are potent inhibitors of virus infection. Proc Natl Acad Sci U S A 1994, 91:9770-9774.

46. Furuta RA, Wild CT, Weng Y, Weiss CD: Capture of an early fusion-active conformation of HIV-1 gp41. Nat Struct Biol 1998, 5:276-279.

47. Luftig MA, Mattu M, Di GP, Geleziunas R, Hrin R, Barbato G, Bianchi E, Miller MD, Pessi A, Carfi A: Structural basis for HIV-1 neutralization by a gp41 fusion intermediate-directed antibody. Nat Struct Mol Biol 2006, 13:740-747.

48. Corti D, Langedijk JP, Hinz A, Seaman MS, Vanzetta F, FernandezRodriguez BM, Silacci C, Pinna D, Jarrossay D, Balla-Jhagjhoorsingh S, Willems B, Zekveld MJ, Dreja H, O'Sullivan E, Pade C, Orkin C, Jeffs SA, Montefiori DC, Davis D, Weissenhorn W, McKnight A, Heeney JL, Sallusto F, Sattentau QJ, Weiss RA, Lanzavecchia A: Analysis of memory B cell responses and isolation of novel monoclonal antibodies with neutralizing breadth from HIV-1-infected individuals. PLOS One 2010, 5: e8805.

49. Dimitrov AS, Jacobs A, Finnegan CM, Stiegler $G$, Katinger $H$, Blumenthal R: Exposure of the membrane-proximal external region of HIV-1 gp41 in the course of HIV-1 envelope glycoprotein-mediated fusion. Biochemistry 2007, 46:1398-1401.

50. Frey G, Peng H, Rits-Volloch S, Morelli M, Cheng Y, Chen B: A fusionintermediate state of HIV-1 gp41 targeted by broadly neutralizing antibodies. Proc Natl Acad Sci U S A 2008, 105:3739-3744.

51. Letvin NL, Daniel MD, Sehgal PK, Desrosiers RC, Hunt RD, Waldron LM, MacKey JJ, Schmidt DK, Chalifoux LV, King NW: Induction of AIDS-like disease in macaque monkeys with T-cell tropic retrovirus STLV-III. Science 1985, 230:71-73.

52. Estes JD, Gordon SN, Zeng M, Chahroudi AM, Dunham RM, Staprans SI, Reilly CS, Silvestri G, Haase AT: Early resolution of acute immune activation and induction of PD-1 in SIV-infected sooty mangabeys distinguishes nonpathogenic from pathogenic infection in rhesus macaques. J Immunol 2008, 180:6798-6807.

53. Jacquelin B, Mayau V, Targat B, Liovat AS, Kunkel D, Petitjean G, Dillies MA Roques $P$, Butor C, Silvestri G, Giavedoni LD, Lebon P, Barre-Sinoussi F, Benecke A, Muller-Trutwin MC: Nonpathogenic SIV infection of African green monkeys induces a strong but rapidly controlled type I IFN response. J Clin Invest 2009, 119:3544-3555.

54. Silvestri G: Naturally SIV-infected sooty mangabeys: are we closer to understanding why they do not develop AIDS? J Med Primatol 2005 34:243-252.

55. Shedlock DJ, Silvestri G, Weiner DB: Monkeying around with HIV vaccines: using rhesus macaques to define 'gatekeepers' for clinical trials. Nat Rev Immunol 2009, 9:717-728.

56. Van Rompay KK: Evaluation of antiretrovirals in animal models of HIV infection. Antiviral Res 2010, 85:159-175.

57. Kestler HW III, Naidu YN, Kodama T, King NW, Daniel MD, Li Y, Desrosiers RC: Use of infectious molecular clones of simian immunodeficiency virus for pathogenesis studies. J Med Primatol 1989, 18:305-309.

58. Naidu YM, Kestler HW III, Li Y, Butler CV, Silva DP, Schmidt DK, Troup CD, Sehgal PK, Sonigo P, Daniel MD: Characterization of infectious molecular clones of simian immunodeficiency virus (SIVmac) and human immunodeficiency virus type 2: persistent infection of rhesus monkeys with molecularly cloned SIVmac. J Virol 1988, 62:4691-4696.

59. Chen Z, Zhou P, Ho DD, Landau NR, Marx PA: Genetically divergent strains of simian immunodeficiency virus use CCR5 as a coreceptor for entry. J Virol 1997, 71:2705-2714.

60. Edinger AL, Amedee A, Miller K, Doranz BJ, Endres M, Sharron M, Samson M, Lu ZH, Clements JE, Murphey-Corb M, Peiper SC, Parmentier M, Broder CC, Doms RW: Differential utilization of CCR5 by macrophage and T cell tropic simian immunodeficiency virus strains. Proc Natl Acad Sci U S A 1997, 94:4005-4010.

61. Kirchhoff F, Pohlmann S, Hamacher M, Means RE, Kraus T, Uberla K, Di MP: Simian immunodeficiency virus variants with differential T-cell and macrophage tropism use CCR5 and an unidentified cofactor expressed in CEMx174 cells for efficient entry. J Virol 1997, 71:6509-6516.

62. Deng HK, Unutmaz D, Kewalramani VN, Littman DR: Expression cloning of new receptors used by simian and human immunodeficiency viruses. Nature 1997, 388:296-300.

63. Edinger AL, Hoffman TL, Sharron M, Lee B, O'Dowd B, Doms RW: Use of GPR1, GPR15, and STRL33 as coreceptors by diverse human immunodeficiency virus type 1 and simian immunodeficiency virus envelope proteins. Virology 1998, 249:367-378.

64. Dehghani $H$, Puffer BA, Doms RW, Hirsch VM: Unique pattern of convergent envelope evolution in simian immunodeficiency virusinfected rapid progressor macaques: association with CD4-independent usage of CCR5. J Virol 2003, 77:6405-6418.

65. Reeves JD, Hibbitts S, Simmons G, McKnight A, zevedo-Pereira JM, MonizPereira J, Clapham PR: Primary human immunodeficiency virus type 2 (HIV-2) isolates infect CD4-negative cells via CCR5 and CXCR4: comparison with HIV-1 and simian immunodeficiency virus and relevance to cell tropism in vivo. J Virol 1999, 73:7795-7804.

66. Puffer BA, Altamura LA, Pierson TC, Doms RW: Determinants within gp120 and gp41 contribute to CD4 independence of SIV Envs. Virology 2004 327:16-25.

67. Pohlmann S, Davis C, Meister S, Leslie GJ, Otto C, Reeves JD, Puffer BA, Papkalla A, Krumbiegel M, Marzi A, Lorenz S, Munch J, Doms RW, Kirchhoff F: Amino acid 324 in the simian immunodeficiency virus SIVmac V3 loop can confer CD4 independence and modulate the interaction with CCR5 and alternative coreceptors. J Virol 2004, 78:3223-3232

68. Hoffman TL, LaBranche CC, Zhang W, Canziani G, Robinson J, Chaiken I, Hoxie JA, Doms RW: Stable exposure of the coreceptor-binding site in a CD4-independent HIV-1 envelope protein. Proc Natl Acad Sci U S A 1999, 96:6359-6364. 
69. LaBranche CC, Hoffman TL, Romano J, Haggarty BS, Edwards TG, Matthews TJ, Doms RW, Hoxie JA: Determinants of CD4 independence for a human immunodeficiency virus type 1 variant map outside regions required for coreceptor specificity. J Virol 1999, 73:10310-10319.

70. Bannert N, Schenten D, Craig S, Sodroski J: The level of CD4 expression limits infection of primary rhesus monkey macrophages by a T-tropic simian immunodeficiency virus and macrophagetropic human immunodeficiency viruses. J Virol 2000, 74:10984-10993.

71. Mori K, Rosenzweig M, Desrosiers RC: Mechanisms for adaptation of simian immunodeficiency virus to replication in alveolar macrophages. $J$ Virol 2000, 74:10852-10859.

72. Gustchina E, Hummer G, Bewley CA, Clore GM: Differential inhibition of HIV-1 and SIV envelope-mediated cell fusion by C34 peptides derived from the C-terminal heptad repeat of gp41 from diverse strains of HIV-1, HIV-2, and SIV. J Med Chem 2005, 48:3036-3044.

73. Malashkevich VN, Chan DC, Chutkowski CT, Kim PS: Crystal structure of the simian immunodeficiency virus (SIV) gp41 core: conserved helical interactions underlie the broad inhibitory activity of gp41 peptides. Proc Natl Acad Sci U S A 1998, 95:9134-9139.

74. McKnight A, Wilkinson D, Simmons G, Talbot S, Picard L, Ahuja M, Marsh M, Hoxie JA, Clapham PR: Inhibition of human immunodeficiency virus fusion by a monoclonal antibody to a coreceptor (CXCR4) is both cell type and virus strain dependent. J Virol 1997, 71:1692-1696.

75. Babcock GJ, Farzan M, Sodroski J: Ligand-independent dimerization of CXCR4, a principal HIV-1 coreceptor. J Biol Chem 2003, 278:3378-3385.

76. Zaitseva M, Peden K, Golding H: HIV coreceptors: role of structure, posttranslational modifications, and internalization in viral-cell fusion and as targets for entry inhibitors. Biochim Biophys Acta 2003, 1614:51-61.

77. Oppermann M: Chemokine receptor CCR5: insights into structure, function, and regulation. Cell Signal 2004, 16:1201-1210.

78. Wang J, Babcock GJ, Choe H, Farzan M, Sodroski J, Gabuzda D: N-linked glycosylation in the CXCR4 N-terminus inhibits binding to HIV-1 envelope glycoproteins. Virology 2004, 324:140-150.

79. Sloane AJ, Raso V, Dimitrov DS, Xiao X, Deo S, Muljadi N, Restuccia D, Turville S, Kearney C, Broder CC, Zoellner H, Cunningham AL, Bendall L, Lynch GW: Marked structural and functional heterogeneity in CXCR4: separation of HIV-1 and SDF-1alpha responses. Immunol Cell Biol 2005, 83:129-143.

80. Simpson LS, Zhu JZ, Widlanski TS, Stone MJ: Regulation of chemokine recognition by site-specific tyrosine sulfation of receptor peptides. Chem Biol 2009, 16:153-161.

81. Farzan M, Mirzabekov T, Kolchinsky P, Wyatt R, Cayabyab M, Gerard NP, Gerard C, Sodroski J, Choe H: Tyrosine sulfation of the amino terminus of CCR5 facilitates HIV-1 entry. Cell 1999, 96:667-676.

82. Lam SN, Acharya P, Wyatt R, Kwong PD, Bewley CA: Tyrosine-sulfate isosteres of CCR5 N-terminus as tools for studying HIV-1 entry. Bioorg Med Chem 2008, 16:10113-10120.

83. Farzan M, Vasilieva N, Schnitzler CE, Chung S, Robinson J, Gerard NP, Gerard C, Choe H, Sodroski J: A tyrosine-sulfated peptide based on the N terminus of CCR5 interacts with a CD4-enhanced epitope of the HIV-1 gp120 envelope glycoprotein and inhibits HIV-1 entry2. J Biol Chem 2000, 275:33516-33521.

84. Cormier EG, Persuh M, Thompson DA, Lin SW, Sakmar TP, Olson WC, Dragic T: Specific interaction of CCR5 amino-terminal domain peptides containing sulfotyrosines with HIV-1 envelope glycoprotein gp120. Proc Natl Acad Sci U S A 2000, 97:5762-5767.

85. Farzan M, Mirzabekov T, Kolchinsky P, Wyatt R, Cayabyab M, Gerard NP, Gerard C, Sodroski J, Choe H: Tyrosine sulfation of the amino terminus of CCR5 facilitates HIV-1 entry 3. Cell 1999, 96:667-676.

86. Bannert N, Craig S, Farzan M, Sogah D, Santo NV, Choe H, Sodroski J: Sialylated O-glycans and sulfated tyrosines in the $\mathrm{NH} 2$-terminal domain of CC chemokine receptor 5 contribute to high affinity binding of chemokines. J Exp Med 2001, 194:1661-1673.

87. Venkatesan S, Petrovic A, Locati M, Kim YO, Weissman D, Murphy PM: A membrane-proximal basic domain and cysteine cluster in the C-terminal tail of CCR5 constitute a bipartite motif critical for cell surface expression. J Biol Chem 2001, 276:40133-40145.

88. Blanpain C, Wittamer V, Vanderwinden JM, Boom A, Renneboog B, Lee B, Le PE, El AL, Govaerts C, Vassart G, Doms RW, Parmentier M: Palmitoylation of CCR5 is critical for receptor trafficking and efficient activation of intracellular signaling pathways. J Biol Chem 2001, 276:23795-23804.
89. Percherancier $Y$, Planchenault T, Valenzuela-Fernandez A, Virelizier $J$, renzana-Seisdedos F, Bachelerie F: Palmitoylation-dependent control of degradation, life span, and membrane expression of the CCR5 receptor. J Biol Chem 2001, 276:31936-31944.

90. Kraft K, Olbrich H, Majoul I, Mack M, Proudfoot A, Oppermann M: Characterization of sequence determinants within the carboxyl-terminal domain of chemokine receptor CCR5 that regulate signaling and receptor internalization. J Biol Chem 2001, 276:34408-34418.

91. Steffens CM, Hope TJ: Mobility of the human immunodeficiency virus (HIV) receptor CD4 and coreceptor CCR5 in living cells: implications for HIV fusion and entry events. J Virol 2004, 78:9573-9578.

92. Popik W, Alce TM, Au WC: Human immunodeficiency virus type 1 uses lipid raft-colocalized CD4 and chemokine receptors for productive entry into CD4(+) T cells. J Virol 2002, 76:4709-4722.

93. Berson JF, Long D, Doranz BJ, Rucker J, Jirik FR, Doms RW: A seventransmembrane domain receptor involved in fusion and entry of T-celltropic human immunodeficiency virus type 1 strains. J Virol 1996, 70:6288-6295.

94. Chabot DJ, Chen H, Dimitrov DS, Broder CC: N-linked glycosylation of CXCR4 masks coreceptor function for CCR5-dependent human immunodeficiency virus type 1 isolates. J Virol 2000, 74:4404-4413.

95. Brelot A, Heveker N, Montes M, Alizon M: Identification of residues of CXCR4 critical for human immunodeficiency virus coreceptor and chemokine receptor activities. J Biol Chem 2000, 275:23736-23744.

96. Thordsen I, Polzer S, Schreiber M: Infection of cells expressing CXCR4 mutants lacking $\mathrm{N}$-glycosylation at the $\mathrm{N}$-terminal extracellular domain is enhanced for R5X4-dualtropic human immunodeficiency virus type-1. BMC Infect Dis 2002, 2:31.

97. Weissman D, Rabin RL, Arthos J, Rubbert A, Dybul M, Swofford R, Venkatesan S, Farber JM, Fauci AS: Macrophage-tropic HIV and SIV envelope proteins induce a signal through the CCR5 chemokine receptor. Nature 1997, 389:981-985

98. Davis CB, Dikic I, Unutmaz D, Hill CM, Arthos J, Siani MA, Thompson DA, Schlessinger J, Littman DR: Signal transduction due to HIV-1 envelope interactions with chemokine receptors CXCR4 or CCR5. J Exp Med 1997, 186:1793-1798.

99. Busillo JM, Benovic JL: Regulation of CXCR4 signaling. Biochim Biophys Acta 2007, 1768:952-963.

100. Wu Y, Yoder A: Chemokine coreceptor signaling in HIV-1 infection and pathogenesis. PLoS Pathog 2009, 5:e1000520.

101. Sotsios Y, Whittaker GC, Westwick J, Ward SG: The CXC chemokine stromal cell-derived factor activates a Gi-coupled phosphoinositide 3-kinase in $\mathrm{T}$ lymphocytes. J Immunol 1999, 163:5954-5963.

102. Vicente-Manzanares M, Rey M, Jones DR, Sancho D, Mellado M, RodriguezFrade JM, del Pozo MA, Yanez Mo M, de Ana AM, Martinez A, Merida I, Sanchez-Madrid F: Involvement of phosphatidylinositol 3-kinase in stromal cell-derived factor-1 alpha-induced lymphocyte polarization and chemotaxis. J Immunol 1999, 163:4001-4012.

103. Vicente-Manzanares M, Cabrero JR, Rey M, Perez-Martinez M, Ursa A, Itoh K, Sanchez-Madrid F: A role for the Rho-p160 Rho coiled-coil kinase axis in the chemokine stromal cell-derived factor-1alpha-induced lymphocyte actomyosin and microtubular organization and chemotaxis. J Immunol 2002, 168:400-410.

104. Ganju RK, Brubaker SA, Meyer J, Dutt P, Yang Y, Qin S, Newman W, Groopman JE: The alpha-chemokine, stromal cell-derived factor-1alpha, binds to the transmembrane G-protein-coupled CXCR-4 receptor and activates multiple signal transduction pathways. J Biol Chem 1998, 273:23169-23175.

105. Porcile C, Bajetto A, Barbieri F, Barbero S, Bonavia R, Biglieri M, Pirani P, Florio T, Schettini G: Stromal cell-derived factor-1alpha (SDF-1alpha/ CXCL12) stimulates ovarian cancer cell growth through the EGF receptor transactivation. Exp Cell Res 2005, 308:241-253.

106. Barbero S, Bonavia R, Bajetto A, Porcile C, Pirani P, Ravetti JL, Zona GL, Spaziante R, Florio T, Schettini G: Stromal cell-derived factor 1alpha stimulates human glioblastoma cell growth through the activation of both extracellular signal-regulated kinases 1/2 and Akt. Cancer Res 2003, 63:1969-1974.

107. Francois F, Klotman ME: Phosphatidylinositol 3-kinase regulates human immunodeficiency virus type 1 replication following viral entry in primary CD4+ T lymphocytes and macrophages. J Virol 2003, 77:2539-2549. 
108. Balabanian K, Harriague J, Decrion C, Lagane B, Shorte S, Baleux F, Virelizier $J$, renzana-Seisdedos F, Chakrabarti LA: CXCR4-tropic HIV-1 envelope glycoprotein functions as a viral chemokine in unstimulated primary CD4+ T lymphocytes. J Immunol 2004, 173:7150-7160.

109. Cicala C, Arthos J, Censoplano N, Cruz C, Chung E, Martinelli E, Lempicki RA, Natarajan V, VanRyk D, Daucher M, Fauci AS: HIV-1 gp120 induces NFAT nuclear translocation in resting CD4+ T-cells. Virology 2006, 345:105-114.

110. Yoder A, Yu D, Dong L, lyer SR, Xu X, Kelly J, Liu J, Wang W, Vorster PJ, Agulto L, Stephany DA, Cooper JN, Marsh JW, Wu Y: HIV envelope-CXCR4 signaling activates cofilin to overcome cortical actin restriction in resting CD4 T cells. Cell 2008, 134:782-792.

111. Burton DR, Desrosiers RC, Doms RW, Koff WC, Kwong PD, Moore JP, Nabel GJ, Sodroski J, Wilson IA, Wyatt RT: HIV vaccine design and the neutralizing antibody problem. Nat Immunol 2004, 5:233-236.

112. Schulke N, Vesanen MS, Sanders RW, Zhu P, Lu M, Anselma DJ, Villa AR, Parren PW, Binley JM, Roux KH, Maddon PJ, Moore JP, Olson WC: Oligomeric and conformational properties of a proteolytically mature, disulfide-stabilized human immunodeficiency virus type $1 \mathrm{gp} 140$ envelope glycoprotein. J Virol 2002, 76:7760-7776.

113. Srivastava IK, VanDorsten K, Vojtech L, Barnett SW, Stamatatos L: Changes in the immunogenic properties of soluble gp140 human immunodeficiency virus envelope constructs upon partial deletion of the second hypervariable region. J Virol 2003, 77:2310-2320.

114. Yang X, Lee J, Mahony EM, Kwong PD, Wyatt R, Sodroski J: Highly stable trimers formed by human immunodeficiency virus type 1 envelope glycoproteins fused with the trimeric motif of T4 bacteriophage fibritin. J Virol 2002, 76:4634-4642.

115. Yang X, Florin L, Farzan M, Kolchinsky P, Kwong PD, Sodroski J, Wyatt R: Modifications that stabilize human immunodeficiency virus envelope glycoprotein trimers in solution. J Virol 2000, 74:4746-4754.

116. Yang $X$, Farzan M, Wyatt $R$, Sodroski J: Characterization of stable, soluble trimers containing complete ectodomains of human immunodeficiency virus type 1 envelope glycoproteins. J Virol 2000, 74:5716-5725.

117. Earl PL, Broder CC, Long D, Lee SA, Peterson J, Chakrabarti S, Doms RW, Moss $B$ : Native oligomeric human immunodeficiency virus type 1 envelope glycoprotein elicits diverse monoclonal antibody reactivities. J Virol 1994, 68:3015-3026.

118. Binley JM, Sanders RW, Clas B, Schuelke N, Master A, Guo Y, Kajumo F, Anselma DJ, Maddon PJ, Olson WC, Moore JP: A recombinant human immunodeficiency virus type 1 envelope glycoprotein complex stabilized by an intermolecular disulfide bond between the gp120 and gp41 subunits is an antigenic mimic of the trimeric virion-associated structure10. J Virol 2000, 74:627-643.

119. Moore PL, Crooks ET, Porter L, Zhu P, Cayanan CS, Grise H, Corcoran P, Zwick MB, Franti M, Morris L, Roux KH, Burton DR, Binley JM: Nature of nonfunctional envelope proteins on the surface of human immunodeficiency virus type 13 . J Virol 2006, 80:2515-2528.

120. Pancera M, Wyatt R: Selective recognition of oligomeric HIV-1 primary isolate envelope glycoproteins by potently neutralizing ligands requires efficient precursor cleavage. Virology 2005, 332:145-156.

121. Sanders RW, Vesanen M, Schuelke N, Master A, Schiffner L, Kalyanaraman R, Paluch M, Berkhout B, Maddon PJ, Olson WC, Lu M, Moore JP: Stabilization of the soluble, cleaved, trimeric form of the envelope glycoprotein complex of human immunodeficiency virus type 1. J Virol 2002, 76:8875-8889.

122. Beddows S, Schulke N, Kirschner M, Barnes K, Franti M, Michael E, Ketas T, Sanders RW, Maddon PJ, Olson WC, Moore JP: Evaluating the immunogenicity of a disulfide-stabilized, cleaved, trimeric form of the envelope glycoprotein complex of human immunodeficiency virus type 1. J Virol 2005, 79:8812-8827.

123. Selvarajah S, Puffer BA, Lee FH, Zhu P, Li Y, Wyatt R, Roux KH, Doms RW, Burton DR: Focused dampening of antibody response to the immunodominant variable loops by engineered soluble gp140. AIDS Res Hum Retroviruses 2008, 24:301-314.

124. Chen B, Cheng Y, Calder L, Harrison SC, Reinherz EL, Skehel JJ, Wiley DC: A chimeric protein of simian immunodeficiency virus envelope glycoprotein gp140 and Escherichia coli aspartate transcarbamoylase. $J$ Virol 2004, 78:4508-4516.

125. Du SX, Idiart RJ, Mariano EB, Chen $H$, Jiang $P, X u L$, Ostrow KM, Wrin T, Phung P, Binley JM, Petropoulos CJ, Ballantyne JA, Whalen RG: Effect of trimerization motifs on quaternary structure, antigenicity, and immunogenicity of a noncleavable HIV-1 gp140 envelope glycoprotein. Virology 2009, 395:33-44.

126. Grovit-Ferbas K, Hsu JF, Ferbas J, Gudeman V, Chen IS: Enhanced binding of antibodies to neutralization epitopes following thermal and chemical inactivation of human immunodeficiency virus type 13 . J Virol 2000, 74:5802-5809.

127. Grundner C, Mirzabekov T, Sodroski J, Wyatt R: Solid-phase proteoliposomes containing human immunodeficiency virus envelope glycoproteins 1. J Virol 2002, 76:3511-3521.

128. Race E, Frezza P, Stephens DM, Davis D, Polyanskaya N, Cranage M, Oxford JS: An experimental chemically inactivated HIV-1 vaccine induces antibodies that neutralize homologous and heterologous viruses 3 . Vaccine 1995, 13:54-60.

129. Buonaguro L, Buonaguro FM, Tornesello ML, Mantas D, Beth-Giraldo $E$ Wagner R, Michelson S, Prevost M-C, Wolf H, Giraldo G: High efficient production of Pr55gag Virus-like Particles expressing multiple HIV-1 epitopes, including a gp120 protein derived from an Ugandan HIV-1 isolate of subtype A. Antiviral Research 2001, 49:35-47.

130. Crooks ET, Moore PL, Franti M, Cayanan CS, Zhu P, Jiang P, de Vries RP, Wiley C, Zharkikh I, Schulke N, Roux KH, Montefiori DC, Burton DR, Binley JM: A comparative immunogenicity study of HIV-1 virus-like particles bearing various forms of envelope proteins, particles bearing no envelope and soluble monomeric gp120. Virology 2007, 366:245-262.

131. Wang BZ, Liu W, Kang SM, Alam M, Huang C, Ye L, Sun Y, Li Y, Kothe DL, Pushko P, Dokland T, Haynes BF, Smith G, Hahn BH, Compans RW: Incorporation of high levels of chimeric human immunodeficiency virus envelope glycoproteins into virus-like particles. J Virol 2007, 81:10869-10878.

132. Gheysen D, Jacobs E, de Foresta F, Thiriart C, Francotte M, Thines D, De Wilde M: Assembly and release of HIV-1 precursor Pr55 $5^{\text {gag }}$ virus-like particles from recombinant baculovirus-infected insect cells. Cell 1989, 59:103-112.

133. Delchambre M, Gheysen D, Thines D, Thiriart C, Jacobs E, Verdin E, Horth M, Burny A, Bex F: The GAG precursor of simian immunodeficiency virus assembles into virus-like particles. EMBOJ 1989, 8:2653-2660.

134. Miyanohara A, Imamura T, Araki M, Sugawara K, Ohtomo N, Matsubara K: Expression of hepatitis $B$ virus core antigen gene in Saccharomyces cerevisiae: synthesis of two polypeptides translated from different initiation codons. J Virol 1986, 59:176-180.

135. Kirnbauer R, Booy F, Cheng N, Lowy DR, Schiller JT: Papillomavirus L1 major capsid protein self-assembles into virus- like particles that are highly immunogenic. Proc Natl Acad Sci USA 1992, 89:12180-12184.

136. Takamura S, Niikura M, Li TC, Takeda N, Kusagawa S, Takebe Y, Miyamura T, Yasutomi Y: DNA vaccine-encapsulated virus-like particles derived from an orally transmissible virus stimulate mucosal and systemic immune responses by oral administration. Gene Ther 2004, 11:628-635.

137. Malboeuf CM, Simon DA, Lee YE, Lankes HA, Dewhurst S, Frelinger JG, Rose RC: Human papillomavirus-like particles mediate functional delivery of plasmid DNA to antigen presenting cells in vivo. Vaccine 2007, 25:3270-3276.

138. Touze A, Coursaget $P$ : In vitro gene transfer using human papillomaviruslike particles. Nucleic Acids Res 1998, 26:1317-1323.

139. Xu YF, Zhang YQ, Xu XM, Song GX: Papillomavirus virus-like particles as vehicles for the delivery of epitopes or genes. Arch Virol 2006, 151:2133-2148.

140. Buonaguro L, Tornesello ML, Buonaguro FM: Virus-Like Particles as Particulate Vaccines. Curr HIV Res 2010.

141. Fernandez-San MA, Ortigosa SM, Hervas-Stubbs S, Corral-Martinez P, SeguiSimarro JM, Gaetan J, Coursaget P, Veramendi J: Human papillomavirus L1 protein expressed in tobacco chloroplasts self-assembles into virus-like particles that are highly immunogenic. Plant Biotechnol J 2008, 6:427-441.

142. Lopez de Turiso JA, Cortes E, Martinez C, Ruiz de YR, Simarro I, Vela C, Casal I: Recombinant vaccine for canine parvovirus in dogs. J Virol 1992, 66:2748-2753.

143. Brautigam S, Snezhkov E, Bishop DH: Formation of poliovirus-like particles by recombinant baculoviruses expressing the individual VPO, VP3, and VP1 proteins by comparison to particles derived from the expressed poliovirus polyprotein. Virology 1993, 192:512-524.

144. French TJ, Roy P: Synthesis of bluetongue virus (BTV) corelike particles by a recombinant baculovirus expressing the two major structural core proteins of BTV. J Virol 1990, 64:1530-1536. 
145. Kozlovska TM, Cielens I, Dreilinna D, Dislers A, Baumanis V, Ose V, Pumpens P: Recombinant RNA phage $Q$ beta capsid particles synthesized and self-assembled in Escherichia coli. Gene 1993, 137:133-137.

146. Peabody DS, Manifold-Wheeler B, Medford A, Jordan SK, do Carmo CJ, Chackerian B: Immunogenic display of diverse peptides on virus-like particles of RNA phage MS2. J Mol Biol 2008, 380:252-263.

147. Klovins J, Overbeek GP, van den Worm SH, Ackermann HW, van DJ: Nucleotide sequence of a ssRNA phage from Acinetobacter: kinship to coliphages. J Gen Virol 2002, 83:1523-1533.

148. Yamshchikov GV, Ritter GD, Vey M, Compans RW: Assembly of SIV viruslike particles containing envelope proteins using a baculovirus expression system. Virology 1995, 214:50-8.

149. Baumert TF, Ito S, Wong DT, Liang TJ: Hepatitis $C$ virus structural proteins assemble into viruslike particles in insect cells. J Virol 1998, 72:3827-36.

150. McAleer WJ, Buynak EB, Maigetter RZ, Wampler DE, Miller WJ, Hilleman MR: Human hepatitis B vaccine from recombinant yeast. Nature 1984, 307:178-180

151. Kang SM, Song JM, Quan FS, Compans RW: Influenza vaccines based on virus-like particles. Virus Res 2009, 143:140-146.

152. Wagner R, Deml L, Fließbach H, Wanner G, Wolf H: Assembly and extracellular release of chimeric HIV-1 Pr55 ${ }^{\text {gag }}$ retrovirus-like particles. Virology 1994, 200:162-175.

153. Deml L, Kratochwil G, Osterrieder N, Knuchel R, Wolf H, Wagner R: Increased incorporation of chimeric human immunodeficiency virus type 1 gp120 proteins into Pr55gag virus-like particles by an Epstein-Barr virus gp220/350-derived transmembrane domain. Virology 1997, 235:10-25.

154. Tobin GJ, Li GH, Fong SE, Nagashima K, Gonda MA: Chimeric HIV-1 viruslike particles containing gp120 epitopes as a result of a ribosomal frameshift elicit gag- and SU-specific murine cytotoxic T-lymphocyte activities. Virology 1997, 236:307-315.

155. Griffiths JC, Harris SJ, Layton GT, Berrie EL, French TJ, Burns NR, Adams SE, Kingsman AJ: Hybrid human immunodeficiency virus Gag particles as an antigen carrier system: Induction of cytotoxic T-cell and humoral responses by a Gag:V3 fusion. J Virol 1993, 67:3191-3198.

156. Dale CJ, Liu XS, De Rose R, Purcell DF, Anderson J, Xu Y, Leggatt GR, Frazer $\mathrm{IH}$, Kent SJ: Chimeric human papilloma virus-simian/human immunodeficiency virus virus-like-particle vaccines: immunogenicity and protective efficacy in macaques. Virology 2002, 301:176-87.

157. Weber J, Cheinsong-Popov R, Callow D, Adams S, Patou G, Hodgkin K, Martin S, Gotch F, Kingsman A: Immunogenicity of the yeast recombinant $\mathrm{p} 17 / \mathrm{p} 24:$ Ty virus-like particles (p24-VLP) in healthy volunteers. Vaccine 1995, 13:831-834.

158. Schmitz N, Dietmeier K, Bauer M, Maudrich M, Utzinger S, Muntwiler S, Saudan P, Bachmann MF: Displaying Fel d1 on virus-like particles prevents reactogenicity despite greatly enhanced immunogenicity: a novel therapy for cat allergy. J Exp Med 2009, 206:1941-1955.

159. Halsey RJ, Tanzer FL, Meyers A, Pillay S, Lynch A, Shephard E, Williamson AL, Rybicki EP: Chimaeric HIV-1 subtype C Gag molecules with large in-frame C-terminal polypeptide fusions form virus-like particles. Virus Res 2008, 133:259-268.

160. Buonaguro L, Racioppi L, Tornesello ML, Arra C, Visciano ML, Biryahwaho B, Sempala SDK, Giraldo G, Buonaguro FM: Induction of neutralizing antibodies and CTLs in Balb/c mice immunized with Virus-like Particles presenting a gp120 molecule from a HIV-1 isolate of clade A (HIVVLPAs). Antiviral Research 2002, 54:189-201.

161. Buonaguro L, Visciano ML, Tornesello ML, Tagliamonte M, Biryahwaho B, Buonaguro FM: Induction of systemic and mucosal cross-clade neutralizing antibodies in BALB/C mice immunized with human immunodeficiency virus type 1 clade A virus-like particles administered by different routes of inoculation. J Virol 2005, 79:7059-7067.

162. Buonaguro L, Devito C, Tornesello ML, Schroder U, Wahren B, Hinkula J, Buonaguro FM: DNA-VLP prime-boost intra-nasal immunization induces cellular and humoral anti-HIV-1 systemic and mucosal immunity with cross-clade neutralizing activity. Vaccine 2007, 25:5968-5977.

163. Triyatni M, Saunier B, Maruvada P, Davis AR, Ulianich L, Heller T, Patel A, Kohn LD, Liang TJ: Interaction of hepatitis $C$ virus-like particles and cells: a model system for studying viral binding and entry. J Virol 2002, 76:9335-9344
164. Buonaguro L, Tornesello ML, Tagliamonte M, Gallo RC, Wang LX, KaminLewis R, Abdelwahab S, Lewis GK, Buonaguro FM: Baculovirus-derived human immunodeficiency virus type 1 virus-like particles activate dendritic cells and induce ex vivo T-cell responses. J Virol 2006, 80:9134-9143.

doi:10.1186/1479-5876-9-S1-S1

Cite this article as: Tagliamonte et al:: Conformational HIV-1 Envelope on particulate structures: a tool for chemokine coreceptor binding studies. Journal of Translational Medicine 2010 9(Suppl 1):S1.

\section{Submit your next manuscript to BioMed Central and take full advantage of:}

- Convenient online submission

- Thorough peer review

- No space constraints or color figure charges

- Immediate publication on acceptance

- Inclusion in PubMed, CAS, Scopus and Google Scholar

- Research which is freely available for redistribution

Submit your manuscript at www.biomedcentral.com/submit
C Biomed Central 